\title{
LEGAL PROTECTION OF INDONESIAN LABOR IN MANAGEMENT OF HOUSEHOLD OVERSEAS
}

\author{
Arpangi \\ Sultan Agung Islamic University \\ arpangi@unissula.ac.id
}

\begin{abstract}
Protection of Indonesian Migrant Workers abroad is regulated in Act number 18 of 2017 concerning Protection of Indonesian Migrant Workers. Many Indonesian workers work abroad due to the explosion of very high population, which triggers very high unemployment. This research use library research (qualitative research), and is qualitative, descriptive analysis. Literature research, which examines a number of literature relevant to the problem of this writing. Data analysis used in this study is descriptivequalitative by analyzing data / information obtained through descriptive research with library research which is then systematically compiled and described qualitatively. Suggestions that can be delivered related to legal protection according to Law No.18 of 2017 is to increase the guidance and counseling for Indonesian Migrant Workers who will work, so that the Indonesian Migrant Workers is ready to be deployed. Based on article 88 of Law No. 18 of 2017 then the government should create a body as mandated by Law No. 18 of 2017 so that the protection of Indonesian Migrant Workers abroad can run effectively.
\end{abstract}

Keywords: Indonesian Labor; Legal Protection; Management Household.

\section{A. INTRODUCTION}

Indonesia is a country that is on the equator, so it has a variety of potential, the potential is in the form of abundant natural resources and also Indonesia is a country that has a large population so that human resources or labor are abundant. These potentials are spread in 33 provinces of Indonesia, the total area of Indonesia is $1,910,931.32 \mathrm{~km} 2$ and based on the results of the population census as of 30 June 2016 the total population of Indonesia is $257,912,349$ people. When we talk about the availability of employment, we will talk about the unemployment rate located in urban areas and in rural areas. The unemployment rate in Indonesia since the monetary crisis began in early July 1997 to 2016 has increased. Work is a fundamental need for all human beings to meet the needs in their lives.

Basically, the sad condition of Indonesian workers is due to the emergence of tyrannical developed countries' agendas through tempting economic globalization. Noam Chomsky's explanation above seems to have taken place through the extension of the agents of globalization, namely the World Trade Organization or abbreviated as WTO. This is shown by the existence of historical facts which explain that 
discussions related to labor in WTO meetings can be seen as a form of protection against the Multy National Corporation and Trans-National Corporation originating from developed countries that have power and influence in the United Nations. This can be seen from the existence of trading dumping practices in the free market, one of which is by lowering the wages of laborers to reduce the number of goods produced to gain the maximum profit in free trade.

In the era of globalization, foreign workers are free to enter Indonesia, due to the existence of the ASEAN Economic Community, whose implementation began in 2015. The implementation of the ASEAN Economic Community will place Indonesia as a major market for both the flow of goods and investment. From the aspect of employment there is a huge opportunity especially for job seekers because there will be jobs with a variety of diverse expertise needs. The presence of foreign workers is a real reality, and even plays an important role in supporting the functioning of the economic sector in Indonesia. ${ }^{1}$

In order to tackle economic growth and employment, the Indonesian government has tried to attract foreign investors to invest in Indonesia. Whereas in order to overcome one of the problems in Indonesia, namely labor and unemployment issues, what is needed is investment or the movement of the real sector where currently there are

1 Fitratunnisa, Dampak Tenaga Kerja Asing Terhadap Sosial Kemasyarakat Masyarakat Kota Dumai, JOM FISIP, Vol.4 No.1 Februari 2016, P.1-15 no good prospects. With the development of the real sector and investment not yet happening, there is a large amount of unemployment, this is because there is an imbalance between the availability of jobs and employment. 2

The low self-safety guarantee for Indonesian workers is a risk that must be taken in view of the strong drive to seek work abroad. The main factor driving this labor migration is the difference in labor wages in Indonesia and the country visited by migrant workers. They will actually choose to work domestically if the gap in nominal wage gap between the two is not too far away. 3

Considering the importance of workers for many parties, it can be understood if employment development as an integral part of national development based on the Pancasila and the 1945 Constitution of the Republic of Indonesia, Indonesian workers abroad who are based on economic factors to meet their daily needs are the main factors the enthusiasm of Indonesian citizens to become an Indonesian Migrant Worker abroad. Placement of services for workers abroad with a mechanism that has been set both through the Regulation of the Minister of Manpower and Transmigration RI Number: PER-19 / MEN / V / 2006 concerning the implementation and protection of Indonesian Workers

2 Arpangi, Pelindungan Hukum Terhadap Tenaga Kerja Indonesia Di Luar Negeri, Jurnal Pembaharuan Hukum, Vol. III No. 1 Januari-April 2016, P.149-156

3 S. Djuni Prihatin, Potret Buram Perlindungan Tenaga Kerja Indonesia, Jurnal I/mu Sosial \& Ilmu politik, Vol. 10, No,.3 Maret 2007. P.325-342. 
abroad, the Decree of the Minister of Manpower is considered as one of the efforts effective to overcome the problem.

As a result of the presence of Indonesian workers abroad, this has caused new problems, it is because Indonesian workers do not have protection when the workers have problems in the country where the workers work. It can be illustrated that the current conditions of the need for overseas workers are still dominated by workers workers in the informal sector, especially household workers or often called female workers.

This situation is caused by the quality of indonesian workers being below when compared to other countries, so training and skills need to be provided for workers to be dispatched abroad. Now indonesian migrant workers is increasingly demanded to be more qualified and skilled in the field of work that he does. Human resources development, especially indonesian migrant workers, can be done through training and education carried out by taking into account the development of technology that is always developing and leading to increasing the ability, skills of prospective workers. In this way it is expected to produce a professional and creative indonesian migrant workers in carrying out the work. Professionals must always be taken care of, and developed in accordance with the development needs of the job market to be able to become a competitive indonesian migrant workers. As an effort to be able to create skilled and quality indonesian migrant workers in accordance with needs, it is our responsibility to all the people of indonesia.

Indonesia has formed an institution to protect workers who are abroad, namely the indonesian placement and protection service center for workers (BP3TKI) in the hope of being able to provide maximum protection to indonesian migrant workerss starting from pre, period and after work. It aims to be able to provide security to indonesian migrant workers, be placed to work until the completion of the contract and return to the area of origin. Protection of workers during the placement period is carried out when indonesian migrant workers is abroad, indonesian migrant workers is obliged to report their arrival to the indonesian representative in the destination country. After-placement protection is carried out when indonesian migrant workers returns from the country of destination until it arrives in the area of origin. Providing protection to indonesian migrant workers from the actions of other parties who are not responsible and can harm indonesian migrant workers in returning.

\section{B. DISCUSSION}

\section{Legal Protection of Indonesian Migrant Workers Abroad.}

Legal protection is aimed at being able to provide security and peace to prospective indonesian migrant workers, this is as stipulated in the minister of manpower and transmigration which states that when indonesian migrant workers candidates wish to become indonesian migrant workers should be given guidelines 
for behaving properly when becoming indonesian migrant workers, it also serves to direct indonesian migrant workers intentions and objectives desired by the government. It is intended that indonesian migrant workers candidates have competitiveness against foreign workers where the indonesian migrant workers works. For this reason, the state is obliged to guarantee and protect the human rights of indonesian migrant workers who work abroad based on the principle of equality, democracy and justice.

The development of Indonesian legal politics in the protection of migrant workers can be said to be quite slow. After the ratification of Law Number 39 of 2004 concerning the Placement and Protection of Indonesian Workers Abroad, it was only on September 8, 2006 through Presidential Regulation Number 81 of 2006 concerning the National Agency for the Placement and Protection of Indonesian Workers, the Government made little progress regarding the protection of Workers Indonesian Work. However, these regulations did not touch the substance of the protection of migrant workers themselves. The regulation is still in the form of procedural regulations that continue from Law Number 39 of 2004 concerning the Placement and Protection of Overseas Indonesian Workers.4

4 Rizky Dian Bareta, Budi Ispriyarso, Legal Politics Protection of Indonesian Migrant Workers in Full-Phase of Work, Kanun Jurnal IImu Hukum, Vol. 20, No. 1, (April, 2018), P.163-181.
Protection of indonesian migrant workers abroad needs to be carried out in an integrated manner between government agencies both at the central and regional levels and the role of the community is needed in order to form a legal system that protects indonesian migrant workers abroad.

The implementation of the protection of Indonesian Workers includes several things, namely the repatriation shelter, including efforts to provide legal assistance and assistance, rehabilitation/ recovery of physical and psychological health, reintegration/ reunification with their families or their community environment and efforts to empower economic and education so that migrant workers do not get stuck again in the problems he has ever experienced. The indonesian manpower placement and protection service center (BP3TKI) has the duty to provide protection to indonesian migrant workers as much as possible starting from preperiod,during period and after placement, it aims to provide a sense of security to indonesian migrant workers at each stage starting from the initial recruitment process, placement at work, until contract completion and return to the area of origin. ${ }^{5}$

BP3TKI in providing protection for indonesian migrant workers is guided by law number

5 Peni Susetyorini, Perlindungan Tenaga Kerja Indonesia di Luar Negeri Oleh Perwakilan Republik Indonesia, Jurnal Masalah-Masalah Hukum, Vol.39 No.1 (2010), P.65-77. 
18 of 2017 concerning the placement and protection of indonesian migrant workers abroad, it aims to empower and utilize labor force optimally and humanely, guaranteeing and protecting prospective indonesian migrant workers or indonesian migrant workers since at home, in the destination country, until returning to the place of origin in indonesia.

Indonesian migrant workers candidates apparently still do not know about the placement and protection rules for indonesian migrant workers, it is due to lack of knowledge about legal protection at indonesian migrant workers, so that indonesian migrant workers does not know about their rights and obligations while becoming indonesian migrant workers and working abroad. Actually, knowledge of legal protection is an important initial process or element in order to raise public awareness of the law. Without knowledge of legal protection, it would be difficult to expect people to understand the function of the law and also difficult to expect people to obey the law, ultimately it is difficult to realize public awareness of legal protection. However, knowledge and understanding of the law cannot guarantee public awareness of the law if the law is not obeyed or obeyed by the community members.

In the development of the workforce in indonesia abroad, the government needs to pay attention. This is caused by two factors: first, the explosion in the number of job seekers or the increasing number of unemployed people who have an impact on the socio-economy, namely the problem of unemployment and poverty which usually comes more from the countryside. Secondly, the opening of promising employment opportunities in relatively rich countries attracts the attention of indonesian workers to work in these countries. Every worker has the right to obtain protection for occupational safety and health, morals and decency, and treatment in accordance with human dignity and religious values (article 86 paragraph 1 of law number 13 year 2003 concerning labor), then based on this requires the integration of central and regional government agencies and the role of the community needs to provide protection to every worker. Legal protection in terms of work safety has also been specifically regulated in act number 1 of 1970 concerning work safety.

The indonesian manpower placement and protection service center (BP3TKI) in providing protection for indonesian migrant workers is guided by law number 18 of 2017 article 3 concerning the placement and protection of indonesian migrant workers abroad which aims to ensure the fulfillment and enforcement of human rights as indonesian citizens being an indonesian migrant worker abroad, guaranteeing legal, economic and social protection of indonesian migrant workers and their families. Legal protection for indonesian migrant workers in terms of 
protection for bp3tki includes preplacement, placement period and post-placement.

\section{a. Pre-placement protection}

The protection of Indonesian migrant workers is all efforts to protect the interests of prospective Indonesian migrant workers and / or Indonesian migrant workers and their families in realizing guaranteed fulfillment of their rights in all activities before work, during work and after working in legal, economic and economic aspects. social noodles. Protection before work there are all activities to provide protection from registration until departure. Protection while working is an overall activity to provide protection as long as Indonesian migrant workers and family members are abroad. Protection while working is an overall activity to provide protection as long as Indonesian migrant workers and their family members are in the country. ${ }^{6}$

To reduce the occurrence of acts of violence and Indonesian Migrant Workers disputes with employers or with companies, BP3TKI is required to provide protection to Indonesian Migrant Workers while working abroad. The task of BP3TKI is to provide training and education for Indonesian

6 Aga Natalis, Budi Ispriyarso, Politik Hukum Perlindungan Pekerja Migran Perempuan di Indonesia, Pandecta, Vol.13. No.2 December 2018 P.109-123
Migrant Workers candidates who will be sent overseas, education and job training for indonesian migrant workers in order to equip, improve and develop work competencies for prospective indonesian migrant workers. BP3TKI is obliged to provide knowledge and understanding of the situation, conditions of customs, culture, religion in the destination country of work, and the risks of working abroad, while also equipping the ability to communicate in the language of the destination country, providing knowledge and understanding of the rights and obligations of prospective indonesian migrant workers.

BP3TKI requires that every prospective indonesian migrant workers who will go abroad to first attend training conducted by bp3tki and must fulfill the conditions specified to become indonesian migrant workers, have skills or expertise as evidenced by a skills certificate issued by the competent authority. Bp3tki provides a place of education and training for prospective indonesian migrant workers to be dispatched, education and training is carried out at the earliest 20 (twenty) days before indonesian migrant workers's departure abroad. According to article 6 of law number 18 of 2017 that before departure abroad. The following are some of the requirements for work education and training in these areas: 
1) get a job abroad and choose a job according to his competence.

2) gain access to capacity building through work education and training.

3) obtain correct information about the job market, procedures for placement, and working conditions abroad.

4) obtain professional and human services and treatment without discrimination at the time before work, during work, and after work.

5) practice worship in accordance with the religion and beliefs held.

6) get a wage in accordance with the wage standard applicable in the destination country of placement and / or agreement of the two countries and / or the Work Agreement.

7) obtain protection and legal assistance for actions that can reduce dignity in accordance with statutory provisions in Indonesia and in the destination country.

8) obtain an explanation of the rights and obligations as stated in the Work Agreement.

9) gain communication access.

10)mastering travel documents during work.

11)associate and gather in the destination country of placement in accordance with the provisions of the legislation in force in the
destination country of placement.
12)obtain a guarantee of safety and security protection for the return of Indonesian Migrant Workers to their area of origin.

13)obtain documents and work agreements for prospective Indonesian migrant workers and / or Indonesian migrant workers.

\section{b. Placement protection}

period

When labor migrants work in placement countries, migrant workers struggle alone to survive so that the presence of the country is needed by migrant workers. As a form of protection for migrant workers abroad, the government has issued a policy in the form of improving the placement and protection of migrant workers abroad. This is a form of state responsibility towards migrant workers as citizens. This policy includes increasing bilateral cooperation regionally, bilaterally, and multilaterally. ${ }^{7}$

Supervision carried out by BP3TKI of Indonesian Migrant Workers, among others, starting from the arrival, the presence of prospective Indonesian Migrant Workers to the destination country until the contractual contract period

7 Koesrianti, Perlindungan Hukum Pekerja Migran Penata Laksana Rumah Tangga (PLRT) Di Luar Negeri Oleh Negara Ditinjau Dari Konsep Tanggung Jawab Negara, Yustisia. Vol. 4 No. 2 Mei-Agustus 2015, 245-268. 
expires, this is in order to detect the absence of illegal Indonesian Migrant Workers and in accordance with the procedures in Law Number 18 of 2017 about Indonesian Migrant Workers Protection. In protecting the placement period, BP3TKI previously gave directions on the rights and obligations of prospective Indonesian Migrant Workers while working in the destination country. However, there are still Indonesian Migrant Workers who lack the rights and obligations while they are working abroad, each Indonesian Migrant Workers candidate has the same rights and obligations. In fact there are still Indonesian Migrant Workers who have not received their wages according to the standard wages in force in the destination country.

According to Article 6 of

Law Number 18 of 2017 concerning the placement and protection of Indonesian Migrant Workers abroad there are several Indonesian Migrant Workers rights and obligations in the period of placement abroad. The following are some of the rights and obligations of each prospective Indonesian Migrant Workers:

1) get a job abroad and choose a job according to his competence.

2) gain access to self capacity building through work education and training.

3) obtain correct information about the labor market, procedures for placement, and working conditions abroad.

4) obtain professional and humane services and treatment without discrimination at the time before work, during work, and after work.

5) practice worship in accordance with the religion and beliefs held.

6) get a wage in accordance with the wage standard applicable in the country of destination and / or agreement of the two countries and / or the Work Agreement.

7) obtain protection and legal assistance for actions that can reduce dignity in accordance with statutory provisions in Indonesia and in the destination country.

8) obtain an explanation of the rights and obligations as set forth in the Work Agreement.

9) gain communication access.

10)mastering travel documents during work.

11)associate and gather in the destination country of placement in accordance with statutory provisions applicable to the destination country of placement.

12)obtain a guarantee of the protection and safety of returning Indonesian Migrant Workers to their area of origin.

13)obtain documents and work agreements for prospective 
Indonesian migrant workers and / or Indonesian migrant workers.

\section{c. After-placement protection}

Protection at the postplacement stage is carried out when the work agreement has been completed, supervision conducted by BP3TKI is to record and receive reports on the return data of Indonesian Migrant Workers returning to Indonesia, and BP3TKI provides protection during the trip to the originating Indonesian Migrant Workers area. This is in order to avoid the actions of parties who are not responsible for disrupting the journey of the Indonesian Migrant Workers from where they work to where they came from. Regarding the cost of returning everything is borne by the employer or the company concerned, even if there are those who pay for their own trips because the Indonesian Migrant Workers has problems with their employers, violates contractual agreements or has not been officially registered. BP3TKI provides facilities to facilitate Indonesian Migrant Workers's return to their area of origin and provides health facilities for sick Indonesian Migrant Workers on their way back to Indonesia. According to Article 24 of Law Number 18 of 2017 concerning the Protection of Indonesian Migrant Workers, there are several matters concerning the return of Indonesian Migrant Workers who will return to Indonesia.
The following are some matters relating to the protection of returning Indonesian Migrant Workers Protection After Work as referred to in Article 7 letter $c$ includes:
1) facilitation of returning home.
2) settlement of Indonesian Migrant Worker rights that have not been fulfilled.
3) facilitation for the management of Indonesian Migrant Workers who are sick and die.
4) social rehabilitation and social reintegration, and
5) Empowerment of Indonesian Migrant Workers and their families.

\section{The Constraints faced by the Indonesian Workers Placement and Protection Service Center (BP3TKI) to protect Indonesian Migrant Workers Abroad}

The constraints encountered at the indonesian migrant workers placement and protection service center (BP3TKI), namely, there have been several cases of abuse and violations of the rights of indonesian migrant workers (indonesian migrant workers) abroad. Some of the obstacles are caused by the lack of readiness of indonesian migrant workers to work abroad and the language barrier, which has difficulties in communicating. In addition there are also factors that originate from indonesian migrant workers service users, which they overreacted when they encountered work errors made by indonesian migrant 
workers. These problems can occur because the indonesian migrant workers do not know very well about the work to be done and the condition of their destination country, this causes many disputes between workers and employers.

With these problems, BP3TKI should continue to make efforts to educate and educate workers in order to comply with the rules and regulations, in addition to collaborating with partners, namely indonesian migrant workers distribution companies, to be able to provide a full explanation related to the provisions of the employment contract in order to guarantee indonesian migrant workers rights during the term of its employment contract can be fulfilled. In the implementation of work agreements between employers, prospective indonesian migrant workerss and labor distribution companies, a good relationship should be established, because bp3tki as a place for placement of protection services for indonesian migrant workers and intermediaries between indonesian migrant workers and employers if between indonesian migrant workers and the employer occurs in a dispute or problem. If there is a problem between indonesian migrant workers and the employer, bp3tki tries to resolve the problem as well as possible, by peaceful means through consultation. But if the deliberation has been carried out but cannot resolve the problem, then the problem that is happening will be sought assistance to the indonesian government in the country where the indonesian migrant workers works (indonesian embassy).

To solve this problem, it will be hampered because of differences in labor laws between the two countries. There are differences in laws governing work problems that can lead to cases of violence against indonesian migrant workers, and from the existing problems do not get the maximum treatment as expected by the people of indonesia. The striking difference is mainly related to the fulfillment of human rights (ham) and social security for indonesian migrant workers regulated in the law. Provision of protection provided by bp3tki if indonesian migrant workers has a problem can be in the form of assistance with solving cases that are happening at indonesian migrant workers.

Protection of prospective indonesian migrant workers and indonesian migrant workers is carried out in accordance with the requirements stipulated in law no.18 of 2017 concerning protection of migrant workers. From the explanation above it proves that education plays a major role in providing protection for indonesian migrant workers working abroad.

\section{CONCLUSION}

Legal protection for the rights of indonesian migrant workers working abroad has not gone well, this is because of the lack of guidance on the legal meaning for indonesian migrant 
workers, this situation can complicate indonesian migrant workers and eliminate the sense of security for indonesian migrant workers while working abroad. The constraints experienced by bp3tki in implementing legal protection against indonesian migrant workers are due to errors caused

by indonesian migrant workers, that is if there are problems not reporting the problem to the indonesian government in the place where indonesian migrant workers works, this is because the level of education owned by indonesian migrant workers is still low

\section{BIBILIOGRAPHY}

\section{Books:}

Aga Natalis, Budi Ispriyarso, Politik Hukum Perlindungan Pekerja Migran Perempuan di Indonesia, Pandecta, Vol.13. No.2 December 2018;

Arpangi, Pelindungan Hukum Terhadap Tenaga Kerja Indonesia Di Luar Negeri, Jurnal Pembaharuan Hukum, Vol. III No. 1 Januari-April 2016;

Djumadi, 1992, Hukum Perburuhan: Perjanjian Kerja, Rajawali Pers, Jakarta;

Fitratunnisa, Dampak Tenaga Kerja Asing Terhadap Sosial Kemasyarakat Masyarakat Kota Dumai, JOM FISIP, Vol.4 No.1 Februari 2016;

Hartono, Judiantoro, 1992, Segi Hukum Penyelesaian Perselisihan Perburuhan, Rajawali Pers, Jakarta;

Koesrianti, Perlindungan Hukum Pekerja Migran Penata Laksana Rumah Tangga (PLRT) Di Luar Negeri Oleh Negara Ditinjau Dari Konsep Tanggung Jawab Negara, Yustisia. Vol. 4 No. 2 Mei-Agustus 2015;

Peni Susetyorini, Perlindungan Tenaga Kerja Indonesia di Luar Negeri Oleh Perwakilan Republik Indonesia, Jurnal Masalah-Masalah Hukum, Vol.39 No.1 (2010);

Rizky Dian Bareta, Budi Ispriyarso, Legal Politics Protection of Indonesian Migrant Workers in Full-Phase of Work, Kanun Jurnal Ilmu Hukum, Vol. 20, No. 1, (April, 2018);

S. Djuni Prihatin, Potret Buram Perlindungan Tenaga Kerja Indonesia, Jurnal Ilmu Sosial \& Ilmu politik, Vol. 10, No.3 Maret 2007;

Syafei, 1998, Strategi Meningkatkan Daya Saing SDM TKI Memasuki Era Pasar Bebas. Cides dan Depnakertrans, Jakarta

Tjepi F. Aloewic, 1996, Naskah Akademis Tentang Pemutusan Hubungan Kerja dan Penyelesaian Perselisihan Industrial, Cetakan ke-11, BPHN, Jakarta; 